
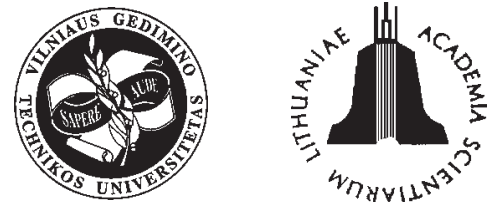

JOURNAL OF CIVIL ENGINEERING AND MANAGEMENT

http:/www.jcem.vgtu.lt

2005, Vol XI, No 3, 169-174

\title{
IMPROVEMENT OF CAPACITY IN BENDING BY THE USE OF FRP LAYERS ON RC BEAMS
}

\author{
Felikss Bulavs, Ivars Radinsh, Normunds Tirans \\ Riga Technical University, Faculty of Civil Engineering, Azenes str 16, LV 1048 Riga, Latvia
}

Received 03 March 2005; accepted 05 July 2005

\begin{abstract}
Carbon-filled plastic bands are more extensively used for strengthening the permanently exploited curved elements. As a result, the bending rigidity of the element is increased and the crack formation process is changed. Investigation of these problems is carried out basing on the model of laminated material, in which the mechanical properties of separate layers may have discreete different values depending on the external load volume. Practical calculations are made by numerical methods which make it possible to follow up the origin of the crack formation in the concrete, by taking into account its non-linear deformation character. The work deals with the analysis of the beam strengthening specific character under unloaded and loaded conditions. Testing of the results is performed by using $2 \mathrm{~m}$ long reinforced concrete beams strengthened with carbon-filled plastic bands.
\end{abstract}

Keywords: beam, deflection, reinforced concrete, calculation methods, carbon plates, crack propagation, bridge.

\section{Introduction}

In order to increase the stiffness and strength of structural elements under specific service conditions, currently the construction practice has introduced the strengthening of reinforced concrete elements with plastic sheets or plastic plates. Beams are one of the most widely used construction elements and their load bearing capacity is generally dependent on the bending moment values. During the process of loading beams are subjected to deformations, which lead to the formation of cracks and changing of deformative properties of beams.

The increase of exploitational loads causes insufficiency of the load bearing capacity of the existing structural elements. Here reinforced polymer composites may help to cope with this unbalance. Carbon plastics with various carbon fibres and binders have gained a wide application. It is possible to find optimal ways for strengthening the reinforced concrete beams by modification of properties of fibres and binders. Extra reinforcement - reinforced plastics - in the tensile zone of bent beams controls the crack opening in the concrete and increases the bending stiffness and strength of beams. The application of carbon plates practically enable to achieve thrice larger bending stiffness.

The key problem in the exploitation of strengthened beams concerns the delamination of carbon layers at the epoxy attached ends. To solve the problem of delamination a number of preventive technologies have been proposed, eg, vertical ties of the attached ends [1,2] and angular profiles of the strengthening elements, a part of which is attached to the outer surface of the beam [3].

Experimental investigations with reinforced concrete beams strengthened by different structures show that deflections of beams are positively affected by carbon layers, ie, they enable to reduce considerably the maximum deflections at specific bending moment values [4-7]. Nevertheless, it should be concluded that these results display a more empiric character, and the effect is not based on principles and relationships of scientifically grounded investigations of laminated structural mechanics. It is generally known that during loading a bent reinforced concrete beam undergoes several deformative structural stages. These are as follows: linear deformability zone in all components of the beam, crack formation in the concrete tension region, non-linear concrete deformability zone in the concrete compressed region, yielding zone of steel reinforcement and the zone following the steel failure. Each component of the beam in all zones is under different stress - deformation conditions and affect differently the value of macro deflection of the beam. Within the framework of the article, prognostication of deformations of bent reinforced concrete beams strengthened with carbon layers during the whole process of loading even up to the loss of their load-bearing capacity has been carried out by using the numerical methods. Simultaneously, results on the stress state changes of definite components (concrete, steel reinforcements, layers of carbon fibre reinforced plastic) and development of critical situations (failure, yielding) at any point of cross-section have been obtained. 


\section{Calculation method of displacements}

A laminated medium model [8] with different geometrical and mechanical properties of layers are used for determining the deflections of strengthened reinforced concrete beams.

Laminated medium mechanics enables to obtain the stress-deformation relationships of each layer for the given external loading, as well as micro deformations of the whole laminated element within the limits of initial assumptions. During the loading, even in the event of originally symmetric structure, reinforced concrete beam structure changes to asymmetric one due to the crack formation and non-linear deformation properties of the concrete. Consequently, the position of neutral axis is changed and redistribution of stresses along the beam height occurs. The article [9] illustrates that maximum deflections of reinforced concrete beams practically are caused by bending moments. Application of the hypothesis of flat cross-section methodology is well grounded for determining the stress state conditions of separate layers for sufficiently long beams $(\mathrm{h} / 1<1 / 10)$. In accordance with the hypothesis, axial stresses are divided along the layers according to $\mathrm{Eq}$

$$
\sigma_{i}=E_{i}\left(y_{i}-\tilde{y}\right) M / D \text {. }
$$

Values of normal stresses in the axial direction of the beam, determined by Eq (1), are constant in each i-layer, and their division along the beam height is discreet. If the number of layers is increased, changes of stresses acquire an increasingly monotonous character.

Notations used in the Eq (1): $E_{i}$ - deformative constant of i-layer (within the limits of elastic deformations it is the module of elasticity of the current layer), $y_{i}-$ position of i-layer, $M$ - bending moment in the respective cross-section. Parameter $D$ takes into account the geometry, deformative properties of separate layers and the position of the neutral axis of a beam $\tilde{y}$

$$
\tilde{y}=\frac{\sum b_{i} E_{i}\left(y_{i}^{2}-y_{i-1}^{2}\right)}{2 \sum b_{i} E_{i} h_{i}} .
$$

It is important to consider the modification of neutral axis position during the loading, and thereby parameter $\tilde{y}$ is functionally submitted to the bending moment value. Thus, the division of stresses at a fixed crosssection along the beams height at different bending moment values is different both by quantity and character. It is based on non-linear deformative properties of the concrete at large stresses and cracking of separate layers when stresses reach the tensile strength. Application of the Eq (1) is highly limited because it refers to the distribution of linear stresses in the cross-section of the beam, which is fixed at the best up to the moment of the initial crack formation at the maximum tensile zone of the beam.

Value of the bending moment bound with the emergence of the initial cracking of the concrete can be determined by the relationship

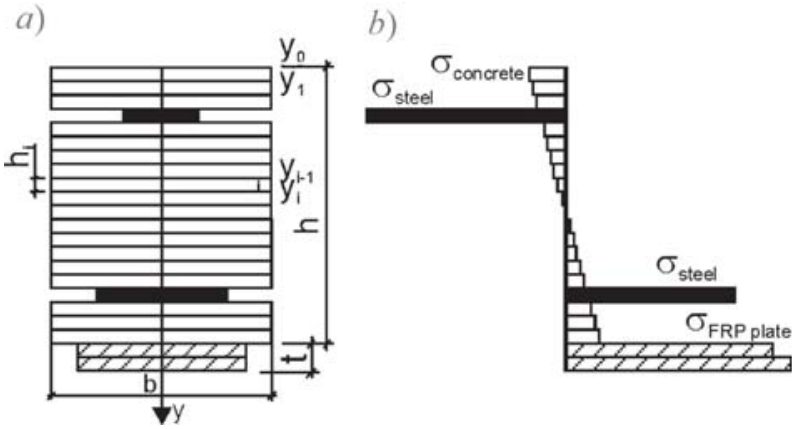

Fig 1. Division of the cross-sectional area of the beam into layers (a) and distribution of axial stresses at initial stage of loading before crack (b) development

$$
M_{c r}=\frac{D \cdot f_{t}}{E_{c}(h-\tilde{y})} .
$$

The position of the neutral axis $\tilde{y}$ at the moment of the initial cracking is determined by the relationship (2).

Depiction of the distribution of axial stresses across the components of the beam (Fig 1b) complies with the schematic illustration of the division of the cross-sectional area of the beam into layers (Fig 1a). Stress in the steel bars and carbon layer during the initial cracking is determined by corresponding equations

$$
\begin{aligned}
& \sigma_{s t}=\frac{E_{s t} f_{t}}{E_{c}} \cdot \frac{y_{s t}-\tilde{y}}{h-\tilde{y}}, \\
& \sigma_{F R P}=\frac{E_{F R P} f_{t}}{E_{c}}\left(1+\frac{t}{2(h-\tilde{y})}\right),
\end{aligned}
$$

where $E_{s t}, E_{c}, E_{F R P}-$ Young's modulus for steel, concrete and composite material, $f_{t}$ - concrete tensile strength.

The stress deformation curve of the stretched concrete is assumed linear. Development of cracks to the centre of the beam brings to a case due to which an increasingly large part of the concrete beam cross-section is not able to bear tensile stresses. For that part it can be assumed that $\sigma=0$. As a result, by increasing the stresses in the compressed section of the concrete, in steel bars and carbon layers, redistribution of stresses in the cross-section of the beam occurs. It is generally known by concrete mechanics that the stress - deformation curve in compression is typically highly non-linear [10]. We have taken it into account in the proposed calculation model by using the deformative parameter, which changes depending on the stress, instead of the concrete module of elasticity. Using the experimentally defined concrete $\sigma-\varepsilon$ curves, changes of the deformative parameter $\tilde{E}=\Delta \sigma / \Delta \varepsilon$ are constructed depending on $\sigma$ diagram. The obtained curved line is approximated by the relationship $\tilde{E}=E_{c}\left(1+\sigma^{n}\right)$, where $E$ is the module of elasticity.

Bending stiffness of the laminated structure is determined by the relationship 


$$
D=\frac{1}{3} \sum b_{i} E_{i}\left(y_{i}^{3}-y_{i-1}^{3}\right)-\frac{\left[\sum b_{i} E_{i}\left(y_{i}^{2}-y_{i-1}^{2}\right)\right]^{2}}{4 \sum b_{i} E_{i} h_{i}}
$$

and is submitted to the loading degree. By increasing the bending moment value, most of the stretched concrete layers do not bear the tensile stresses. It has been taken into account in the calculation model by assuming that the deformative constant of the relevant layer equals zero.

\section{Results of the calculations and experimental justifi- cation}

The proposed calculation methodology was implemented by the computing software and it has been applied in the calculations of two types of reinforced concrete beams [11].

Cross-section dimensions of the first type beams are $200 \times 200 \mathrm{~mm}$ where four $\varnothing 14 \mathrm{~mm}$ steel bars are contained. Mechanical properties of the components provide reference for:

steel - module of elasticity $\mathrm{E}_{\mathrm{st}}=200 \mathrm{GPa}$, yielding stress $\mathrm{f}_{\mathrm{y}}=540 \mathrm{MPa}$;

carbon plate $-\mathrm{E}_{\mathrm{FRP}}=167 \mathrm{GPa}$; tensile strength $\mathrm{f}_{\mathrm{FRP}}=2900 \mathrm{MPa}$, width $\mathrm{b}_{\mathrm{c}}=50 \mathrm{~mm}$, thickness $\mathrm{t}_{\mathrm{c}}=1,3 \mathrm{~mm}$;

concrete $-\mathrm{E}_{\mathrm{c}}=25 \mathrm{GPa}$; tensile strength $\mathrm{f}_{\mathrm{t}}=2,6 \mathrm{MPa}$, compression strength $\mathrm{f}_{\mathrm{c}}=33 \mathrm{MPa}(85 \%$ from the strength of cubes), parameters of deformative properties $\mathrm{a}=-2,73 \cdot 10^{-5}(\mathrm{MPa})^{-3}, \mathrm{n}=3$.

Cross-section dimensions of the second type beams are 300 x $400 \mathrm{~mm}$. They contain five $\varnothing 13 \mathrm{~mm}$ steel bars, three of which located in the stretched zone of the beam, but two of them in the compressed one. Unidirectional carbon layers were used for reinforcing these beams. Mechanical properties of the components for: steel $-\mathrm{E}_{\mathrm{st}}=200 \mathrm{GPa}, \mathrm{R}_{\mathrm{f}}=340 \mathrm{MPa}$; carbon plastic $-\mathrm{E}_{\mathrm{FRP}}=400 \mathrm{GPa} ; \mathrm{f}_{\mathrm{FRP}}=3000 \mathrm{MPa}$, width $\mathrm{b}_{\mathrm{FRP}}=300 \mathrm{~mm}$, thickness $\mathrm{t}=0,17 \mathrm{~mm}$; concrete $-\mathrm{E}_{\mathrm{c}}=25 \mathrm{GPa} ; \mathrm{f}_{\mathrm{t}}=2,6 \mathrm{MPa}, \mathrm{f}_{\mathrm{c}}=33 \mathrm{MPa}$ ( $85 \%$ from the strength of cubes), parameters of deformative properties $\mathrm{a}=-2,73 \cdot 10^{-5}(\mathrm{MPa})^{-3}$, $\mathrm{n}=3$.

Changes of the bending stiffness for several reinforced concrete beam structures by increasing the bending moment have been illustrated in Fig 2 in compliance with the relationship (5).

Curve 1 refers to the first type of beams without carbon reinforcement. Curve 2 describes changes of the bending stiffness for reinforced concrete beams to which three parallel carbon plastic sheets with width $50 \mathrm{~mm}$ and thickness $\mathrm{t}=1,3 \mathrm{~mm}$ have been attached to the stretched zone, whereas curve 3 concerns the case when thickness of the carbon sheet is twice as large, ie, $\mathrm{t}=2,6 \mathrm{~mm}$.

Changes of the bending stiffness for the second type beams are illustrated in curves $4-6$, the width of the car-
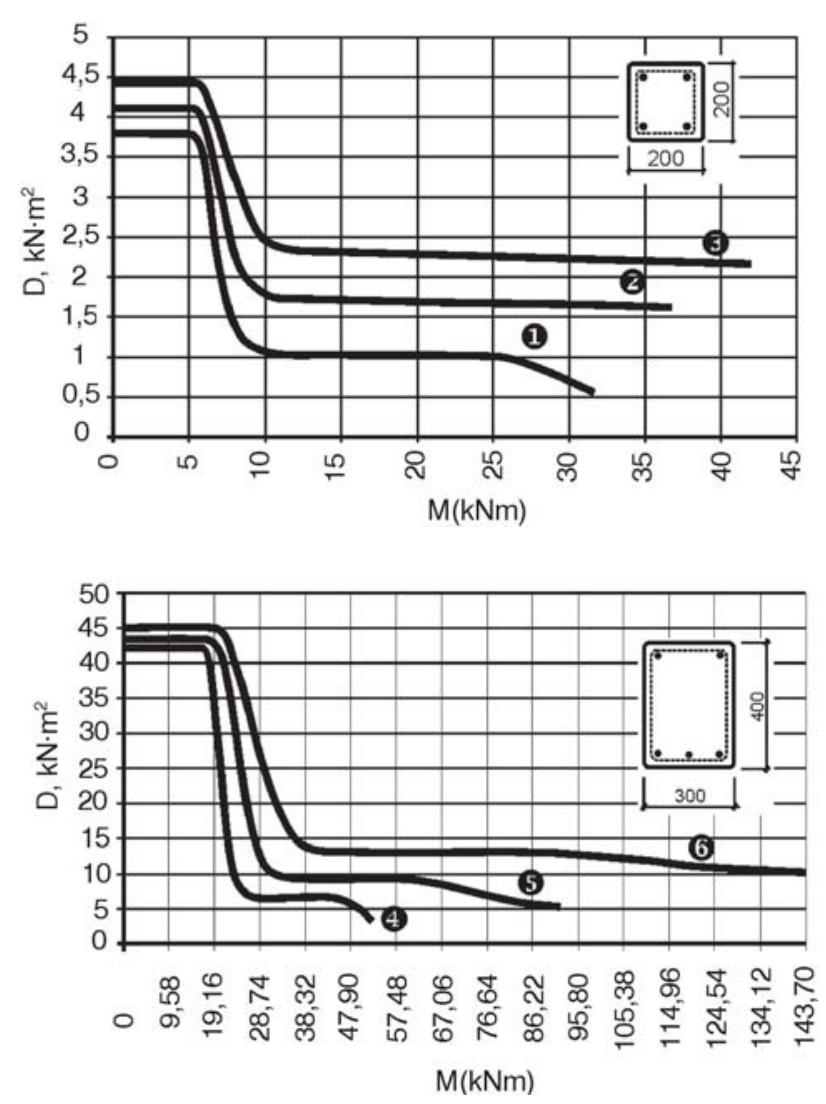

Fig 2. Changes of the bending stiffness in dependence of bending moment for two tipes of beams (description of the curves in text)

bon reinforcement coincides with that of the beam, but the thickness of a layer equals $0,17 \mathrm{~mm}$. Curve 4 refers to the second type of beams without carbon reinforcement. Curve 5 corresponds to the beam reinforced by a single carbon layer, while curve 6 - to the beam with thrice thicker carbon layer. The curves obtained lead up to the conclusion that the carbon type reinforcement has an impact on the bending stiffness of the beam and hence also on deformability. The curves are notable by three loading stages. The first applies to the stage of linear deformability (practically unchageable bending stiffness). That is the initial stage of loading up to the moment of crack emergence in the tensile zone. The stage is relatively small and concerning real loadings insignificant.

The second stage applies to the development of cracks and redistribution of stresses across the components. Here the bending stiffness of the beam considerably changes and these changes must be regarded in the loaded bent elements, because the range of changes of the bending moments is nearly approaching the real loadings of structures. The third stage is peculiar by rising of stresses without relevant redistribution of them in the components. The final result of this stage is the loss of the load bearing capacity of a separate component, which may be the failure of the compressed concrete zone, the beginning of the steel bar yielding or tensile failure of carbon layers. The fourth loading stage of the beam 
develops in case of the steel bar yielding and then excessive loading of carbon layers and deformability of the beam occur. Due to the steel bar yielding delamination of the attached carbon layers is observed, which causes the loss of load bearing capacity of the beam.

Results of the calculations show that the impact of an increased number of carbon layers on the concrete crack formation is insignificant.

It must be taken into account that in cases of real loading different values of the bending moments act in different cross-sections of beams. However, deflections in these cross-sections shall be proportional not only to the bending moment value, they shall also be dependent on the changes caused by the bending moment in the beams structure and deformability features of the concrete (non-linearity).

By application of the proposed methodology maximum deflection curves of beams in case of four-point bending have been determined. Span of the first type beams was $l=2 \mathrm{~m}$, that of the second type beams $l=2,5 \mathrm{~m}$.

The obtained results are illustrated in Fig 3 as continuous lines. Experimental results [11] in case of repeated loading are represented in Fig 3 as dashed lines. The curves are typical by extreme non-linearity and they mark out characteristic loading stages. Maximum deflec-
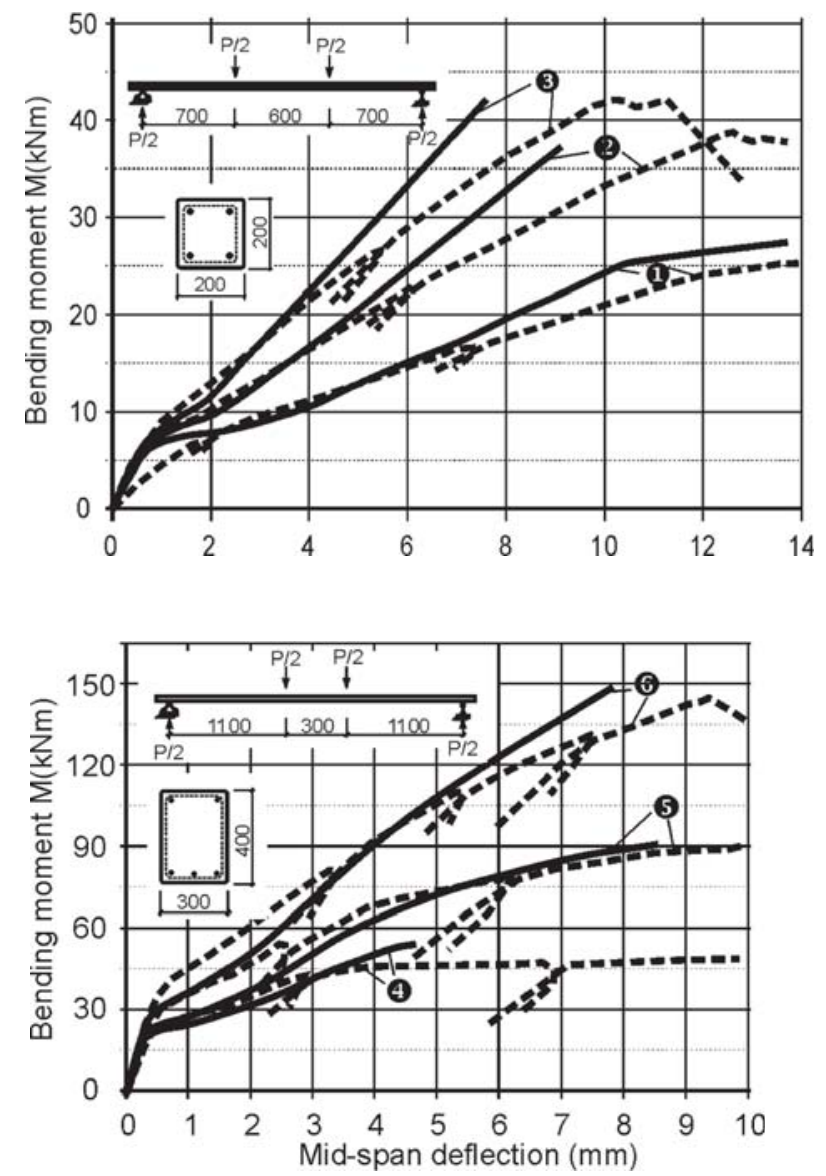

Fig 3. Mid-span deflection of two types of beams (parameters of curves $1-6$ the same as in Fig 2) tions calculated by means of the presented method perfectly correspond to those established by the European codes. The same applies to the experimentally achieved results.

\section{Application of strengthening methods for bridge beams of canal Varkalju}

The presented strengthening methods of bent reinforced concrete elements have been used for 20 years exploited reinforced concrete bridge beams across canal Varkalju on Yurmala ringroad in Riga district, Latvia. It should be observed that the bridge load-bearing structures are in good technical condition. The bridge length is $68 \mathrm{~m}$, divided into $18+24+18 \mathrm{~m}$ spans. The supporting structure is developed by massive reinforced concrete girder supported by two reinforced concrete piles driven up to dolomite bedrock. Span structure is made of prestressed prefabricated reinforced concrete beams according to the standard design.

If conformity of the existing structure is compared to European Standard LVS ENV 1991:2000 requirements, conclusion can be drawn that load-bearing capacity of prestressed beams of canal Varkalju bridge is within the limits of 67 to $75 \%$ out of European Standard loads. The performed calculations show that bridge beams are designed extremely economically basing on the design loads of building regulations effective in the 1980's in Latvia. If the bridge is not strengthened, it is not able to provide the conformity to European Standard loads. Unlike the span structures, the bridge supporting ones possess an adequate load-bearing capacity reserve, so that they can take up both the loads of strengthened and traffic structures in conformity with European Standard LVS ENV 1991:2000 requirements without any additional strengthening operations. Thus the requirement for strengthening the separate bent elements of structures has become a topical problem, which could be solved by glueing carbon plastic tapes to the tension zone of the structure. Strengthening of structures provides the following sequence of operations:

- The existing bituminous concrete covering, dampproofing and cement mortar levelling layer are dismantled. Since the load-bearing capacity of bridge beam shelves is not sufficient, an additional $150 \mathrm{~mm}$ thick reinforced concrete slab (Fig 4a) - a roadway slab thickening - is provided.

- Bridge beams are strengthened by glueing carbon plastic tapes underneath. The amount of these tapes is defined according to the presented calculation scheme. As a result, load-bearing capacity of beam bending is increased.

- Investigation of the oblique cross-sections prove that strengthening of beam walls at the supports is required. It is envisaged to thicken them with reinforced concrete and carbon plastic stickers at the ends of beams. Carbon plastic stickers provide both the strengthening of oblique cross-sections at the 


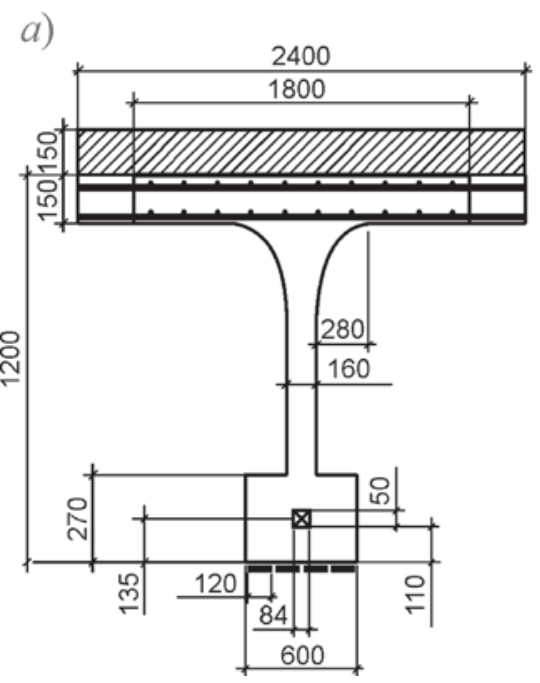

b)

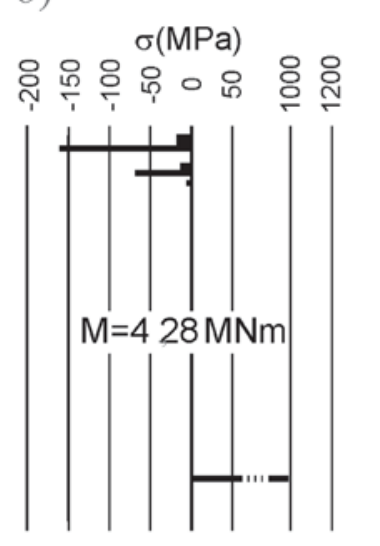

c) $\sigma(\mathrm{MPa})$
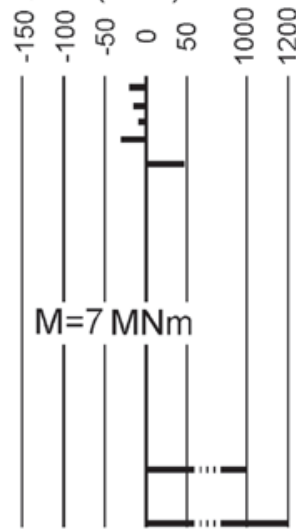

Fig 4. Cross-section of strengthened beam (a) and distribution of stresses in unstrengthened (b) and strengthened beam (c)

ends of beams and also bring under control the delamination of beam strengthening tapes at their ends, thus preventing premature loss of load-bearing capacity of beams.

Up to now a cross-section of the operative reinforced concrete beams can take up the bending moment $4,28 \mathrm{MNm}$. Since the required bending moment to be carried by bridge beams is $7 \mathrm{MNm}$, it results in the development of $63 \%$ of overloading in the beams. Consequently, due to the strengthening the increase of permissible bending moment $2,72 \mathrm{MNm}$ shall be obtained.

According to the presented methods, distribution of the obtained stresses in operative beams is shown in Fig 4b. Description of stresses correspond to the loads caused by the bending moment $4,28 \mathrm{MNm}$. The figure illustrates that tension stresses in steel reinforcements, corresponding to critical bending moment value, have reached the point of steel yielding $980 \mathrm{MPa}$.

Distribution of stresses after 20 year long exploitation with carbon plastic tapes strengthening of beams is shown in Fig 4c. Results are obtained for loads which produce the bending moment $7 \mathrm{MNm}$. Under this critical bending moment value stresses in steel reinforcement reach the point of yielding. Stresses in carbon plastic layers do not exceed $72 \%$ out of the permissible stress $1,68 \mathrm{GPa}$.

As we see in the diagram, cracks have developed in the concrete tension zone, and tension forces are carried only by the reinforcement and carbon plastic strengthening. Diagram of stresses of the compressed zone has taken the shape of a curved line. However, it is obvious that the concrete of the compressed zone is far from failure, therefore the beam can be possibly strengthened by increasing the strengthening volume in the tension zone of the beam.

Calculation model of layered structure [12] has been used for determining beam's bending stiffness D. The results obtained for unstrengthened beams and those strengthened with carbon plastic tapes are depicted as

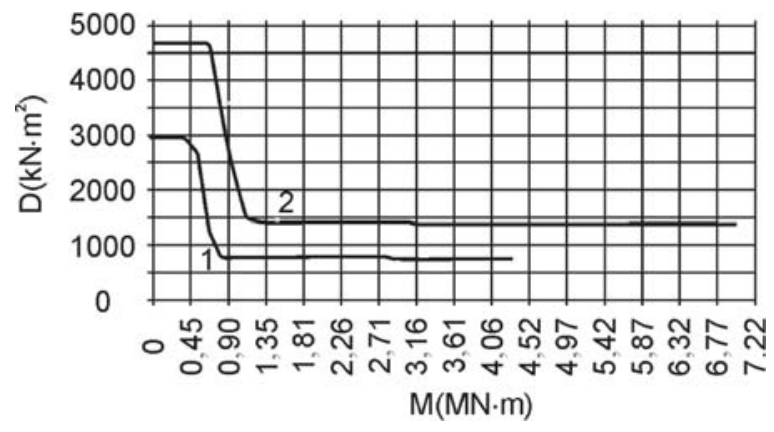

Fig 5. Dependence of bending stiffness of unstrengthened (1) and strengthened (2) beam

curves in Fig 5. The curves are typical broken lines with three characteristic stages: stage of linear deformation (up to the first cracks), crack opening stage and stage of deformation up to the loss of load-bearing capacity (yielding of tension reinforcement). The bending stiffness of strengthened beam is nearly twice higher than of the unstrengthened beam.

In case of Varkalju bridge beams the relative height of concrete compressed zone is 0,0996 , which is considerably smaller than limiting value 0,51 defined by building regulations. So it is possible to strenghten these beams by additional concreting in concrete compressed zone.

\section{Conclusions}

By using the layered structure model a numerical calculation method has been developed for forecasting reinforced concrete beam bending stiffness. The method allows to evaluate the non-linear deformative features of concrete and the crack formation mechanism, extra reinforcement of beams by sheets and plates attached to the beams surface. An advantage of this method is the ability of the proposed model to estimate deflections of reinforced concrete beams for all stages up to disintegra- 
tion. The calculation results comply well with the experimentally obtained results both as to the character and numerical values.

If it is required to strengthen the bent reinforced concrete elements, which include strengthening safety of the compressed zone (they are relatively poorly reinforced), an effective strengthening method is glueing carbon plastic tapes in the tension zone of elements.

The performed calculations demonstrated that eight carbon plastic tapes are enough to increase the load-bearing capacity of a 20 -year operative beam by $63 \%$ on presumption that beam load-bearing capacity is defined by the beginning of yielding of tension steel reinforcements. In case of Varkalu bridge beams the strength safety of carbon plastic layer is $28 \%$. The calculations showed that due to the strengthening of operative beam with eight carbon plastic tapes its bending strength to crack resistance increases by $57 \%$, while in the range of real operative loads - by $88 \%(>0,12 \mathrm{M})$.

Application of carbon plastic layers for beam strengthening open wide possibilities in the increase of bending strength of operative beams as well as of their load-bearing capacity and in the planning of safety of load-bearing capacity.

\section{References}

1. DotDuthich, Monica Starnes. Strength and ductility of concrete beams reinforced with carbon FRP and steel. US Department of Commerce NISTIR, 2001. 44 p.

2. Grace, N. F.; Sayed, G. A.; Soliman, A. K.; Saleh, K. R. Strengthening reinforced concrete beams using fiber reinforced polymer (FRP) laminates. ACI Structural Journal, Vol 96, Issue 5, Sept - Oct 1999, p. 865-874.
3. Bencardino, F.; Spadea, G.; Swamy, R. N. Strength and ductility of reinforced concrete beams externally reinforced with carbon fiber fabric. ACI Structural Journal, Vol 99, Issue 2, March - Apr 2002, p. 163-171.

4. Chajes, M.; Thomson, T. A.; Tarantino, B. Reinforcement of concrete structures using externally bonded composite materials. In: Proceedings, Second International RILEM Symposium FRPRCS-2, Ghent, Belgium, Aug 23-25, E\&FN Spon, London, Vol I, 1995, p. 501-508.

5. Ross, C. A.; Jerome, D. M.; Tedesco, J. W.; Hughes, M. L. Strengthening of reinforced concrete beams with externally bonded composite laminates. ACI Structural Journal, Vol 96, Issue 2, March - Apr 1999, p. 212-220.

6. Saadatmanesh, H.; Ehsani, M. R. Fiber composite plates can strengthen beams. Concrete International, Vol 12, No 3, March 1990, p. 65-71.

7. Saadatmanesh, H.; Ehsani, M. R. RC beams strengthened with GFRP plates - I: Experimental study. Journal of Structural Engineering, Vol 117, No 11, Nov 1991, p. 3417-3433.

8. Skudra, A.; Bulavs, F.; Radinsh, I.; Tirans, N. Regulation of deflections of homogeneous beams. Latvian Journal of Physics and Technical Sciences, No 2, 2003, p. 51-55.

9. Bulavs, F.; Radinsh, I.; Tirans, N. Method of prediction of the deflections of reinforced concrete beams considering cracking. In: Scientific Proceedings of Riga Technical University. Architecture and Construction Science. RTU, Riga, 2003.

10. Neville, A. M. Properties of Concrete, Pitman Publishing Limited, London, 1977.

11. Arduini, M.; Di Tommaso, A.; Nanni, A. Brittle failure in FRP plate and sheet bonded beams. ACI Structural Journal, Vol 94, No 4, July-Aug 1997, p. 363-370.

12. Bulavs, F.; Radinsh, I.; Tirans, N. Model on nonlinearly deforming laminated material. In: $3^{\text {rd }}$ Intern conference "Strength, Durability and Stability of Materials and Structures SDSMS 03", 17-19 Sept, 2003, Klaipėda, Lithuania, p. 24-34.

\section{GELŽBETONINIŲ SIJŲ LAIKOMOSIOS GALIOS PADIDINIMAS TAIKANT DISPERSIŠKAI ARMUOTUS PLASTIKO LAKS̆TUS}

\section{F. Bulavs, I. Radinsh, N. Tirans}

Santrauka

Anglies pluoštu armuoti plastiko lakštai yra dažniausiai naudojama medžiaga ilgą laiką eksploatuojamiems kreivos formos elementams. Ši medžiaga padidina elemento standumą, keičiasi plyšių vystymosi procesas. Sprendžiant šią problemą taikytas sluoksniuotujų medžiagų modelis, kuriame kai kurie sluoksniai (tai priklauso nuo apkrovimo lygio) gali pasižymėti skirtingomis mechaninėmis savybėmis. Praktiniai skaičiavimai atlikti taikant skaitinius metodus, kurie leidžia ịvertinti betono pleišèjimą bei netiesines deformacijas. Pateikta sustiprintosios sijos analizè nukrovimo ir apkrovimo sąlygomis. Atlikta $2 \mathrm{~m}$ ilgio gelžbetoninès sijos, sustiprintos anglies pluoštu armuoto plastiko lakštais, analizè.

Raktažodžiai: sija, įlinkis, gelžbetonis, skaičiavimo metodai, anglies lakštai, plyšių vystymasis, tiltas.

Felikss BULAVS. Professor of the Dept of Structural Analysis of Riga Technical University. His scientific interests are related with composite materials mechanics, and application of these materials in quality improvement of the building produce.

Ivars RADINSH. Head of the Dept of Structural Analysis of RTU, Associate Professor. His scientific interests are related with composite materials mechanics.

Normunds TIRANS. Designer of bridges and building structures, chief engineer in design company "Inzenieru grupa "Kurbads", Latvija, assistant in Riga Technical University. Member of Latvian Civil Engineers' Association. His research interests include the externally bonded fibre reinforced polymer (FRP) reinforcement, particularly the additional reinforcement for reinforced concrete beams strengthening. 